\title{
Mapping socio-physical legacies of Emirati villas: contingency and spatial continuity or rift
}

\author{
Mamun Rashid ${ }^{1 *}$ (D) Dilshad Rahat Ara $^{2}$ (I) and Salem Buhashima Abdalla ${ }^{1}$
}

\begin{abstract}
UAE urban housing and planning history discourses commonly assume a sharp division between the pre-oil (before the 1950s) and the post-oil (since the 1960s) eras. It is a misleading assumption that flattens historical legacies and exempts pre-oil tribal and maritime built landscape from having a bearing on the emergence of more recent 'iconic' villas for the Emiratis/UAE citizens. Besides, status quo urban narratives are further dismissive of non-iconic citizen centric modern housing prototypes of the late 1960s. In this context, our approach is to illustrate the intertwined evolution of contingent driven dwelling features, changes as well as continuities across the pre-oil and post-oil eras. By interconnecting history with user-led spatial changes in current Emirati houses, we argue that, while sustainability has become more of a catchphrase and the 'iconic' villa façade - the marketing brand, the concept, acceptance, and spatial realization are indeed set by historical overlays of local and transnational experimentation, arbitration, and adaptation. Thus, the current design and policy led national housing prototypes would be corrective, regenerative and successful if assembled through an iterative design process that accommodates emerging sustainable frameworks as well as user-driven spatial interventions. This approach sustains the socio-physical legacies of the Emirati houses and their cultural legitimacy in the built-environment.
\end{abstract}

Keywords: Urban villa, Architecture and planning history, Interpretive approach, User-generated accretive spaces, Social and cultural sustainability, Tradition-ultramodernity, Middle East

\section{Introduction}

The current urban housing paradigm in the UAE tends to dismiss the region's pre-oil era (before the 1950s) and its built-scapes as serious entities-devoid of any continuities and contingencies. Indeed, accounts of the UAE's arrival in urban design (the 1960s) scenarios make use of references to oil-fueled urban anomalies, dehistoricized "blank slate" development, and so on. These allusions overlook the region's rich cosmopolitan maritime and diverse pre-oil historical trajectory. Received urban history similarly dismisses non-iconic modern housing prototypes as significant built entities that developed through rigorous local and international exchanges in the

\footnotetext{
*Correspondence: mrashid@sharjah.ac.ae; mamunras@yahoo.com ${ }^{1}$ Department of Architectural Engineering, University of Sharjah, P.O.Box: 27272, Sharjah, United Arab Emirates

Full list of author information is available at the end of the article
}

late 1960s-1970s. This pattern of status-quo approach makes it difficult to understand spatio-temporal changes in UAE citizen centric house patterns and any enduring historical legacies that could be instructive for urban regeneration in the UAE.

In recent history, following an unassuming start in nationally endorsed and internationally instilled social housing (the late 1960s-70 s) prototypes, UAE residential architecture for the Emiratis (Nationals/citizens of the UAE) was refurbished by the villa typology-a standalone house, one or two storeys, placed in a closed perimeter site/plot. Of lately, low density consolidated villas in urban sprawls are branded, offered and sold as stylistic catalogue products e.g., Modern, Andalusian, Islamic, Heritage, American architectural styles by the National Housing Authority, as well as by private real-estate developers (ADHA 2018; Ahmad 2016). At the same time, villas are also promoted in national broadcasts as 
icons of intangible history/heritage and cultural identity. On the other hand, there is a growing recognition by scholars that UAE urbanity faces a deep societal and cultural identity crisis as a result of its interactive position in global networks and open policies in trade, commerce, and more recently tourism. Consequently, since the 1990s heritage and regeneration programs are being reified in the region (Djamel Boussaa 2018; MEI 2008). In this background, the urban villa, a housing prototype for the Emiratis is an intriguing case for further retrospection. The Emiratis (nationals), who make up just about $11 \%$ of the UAE's population, still maintain many socially anchored tribal traditions and practises despite being rapidly modernised into lush urban lifestyles in a very short period of time (AFP 2014; Hawker 2008; Heard-Bey 1997). In light of this interlaced 'tradition' and 'ultra-modern' complexity, this article maps dwelling and housing development for the Emiratis from the pre-oil era to the post-oil.

Indeed a range of time-bound works are available on traditional architecture (predating the modern period), changes in Arabic towns or pre-Islamic archaeological findings in the Gulf literature (Fathy 1972; Hawker 2008; Potts 2012). However, lessons from these studies rarely inform contemporary urban design dialogues. On the other hand, while there has recently been a range of studies available from emerging urban discourses by scholars from within the UAE, there is very little to no systematic study about contemporary urban house form or its transformative pattern that could be meaningfully linked to the past legacies (Alawadi and Benkraouda 2018; Elsheshtawy 2011). Therefore there is no hindsight for any corrective turns for current Emirati house types, architectural design or urban design.

\section{Objectives and methods}

To fill in the above gap of critical works, cross-scalar and temporally grounded research content and regenerative perspectives linking urban house form and the past built-forms, this article is structured in four sections. The first section examines how pre-oil dwellings were diverse not only in types but also in informality and spatial patterns, with privacy, accretions, environmental sensibility and users' engagement as key features. It offers a brief review of the complexity of the social and built setting in the pre-oil era in the hinterlands and along the Trucial Coasts where dynamics of first urban life could be traced. It also examines the nuances of the neighbourhood concept in the traditional setting.

By focusing on the institutionalization of modern planning and fundamental built-environmental changes in the 1960s and 1970s post-oil built scape, the second section traces how Western planning schemes emerged and in the process either modified or erased the multiplicity and diversity of traditional settlements and planning factors. A focus on the planning blueprints and its transnational evolution provides insight into how planning preferences changed over time and yet throughout the process prioritised national houses as experimental urban ensembles. A sub-section zooms in the launching of modern housing and reconstructs local (leadership/Sheikh driven) and transnational dialogues that initiated largely non-iconic social housing for the Emiratis. In these cases, not only Western programs, and international architectural styles, but also traditional customs, coalesced together. Review of publications, drawings and photo records pinpoint to a 'consolidated' core type as well as 'accretive' category of national house types that evolved during this time.

The third section shifts to the post-1970s era/postfederation era, focusing on the recounts of the 'iconic' Emirati villa and pointing to sustainability (Estidama in 2008) branding that departs from previous legacies. The final section speculates on the overarching question: Is the current 'iconic' Emirati villa an antithesis to its cultural precursors (thus a de-contextualized precedent) or a resilient urban hybrid house which has changed but still bears marks of its housing predecessors? To address this speculative query, this section maps what Emiratis change or build after moving in and examines user-generated spatial accretions where historical past is interlaced with contemporary presence. From this position a bottom-up corrective and sustainable urban regeneration direction in architecture/housing/planning discourses in the UAE is suggested. The section is based on the authors' observations and field notes (2008-2020) in Abu Dhabi and Sharjah, the two main Emirates. The mapped directives are also applicable to other Emirates that are slowly catching up with Abu Dhabi's housing agenda. Note that Abu Dhabi is the federal capital of the United Arab Emirates and Emirate of Sharjah is the third-most populous and coastal city in the UAE, after Dubai and Abu Dhabi (For Sharjah's coastal history and urbanism see, Fraser and Golzari 2016; Katodrytis and Mitchell 2015).

\section{Informal dwellings of the Trucial Coast (Pre-oil era)}

The UAE is a peninsular country. Seven emirates along the Arabian Gulf coast of the Arabian Peninsula form the UAE of today: Abu Dhabi, Dubai, Sharjah, Ras alKhaimah, Umm al Qaiwain, Ajman and Fujairah. Formerly these were known as the Trucial States. Life before the 1950s on the Trucial Coast was of stringent survivaladaptation. Tribe was the principal building block of the then-UAE society, with tribal affiliations forming the very bases of the social fabric (Abed and Hellyer 2001; HeardBey 1997; Thesiger 1950; Trench 1996). People gained their traditional identity from their means of livelihood 
along the division Hadhr (settled) and Bedu (mobile), although the division itself was not so simplistic (Cole 2003, p. 237). For example, Hadhr populations followed occupations as sea traders, fishermen, pearlers (bahriyya or ahl al-bahr), cultivators of dates (mazari), and so on. Bedu populations moved between resources. Some of them worked as fishermen (sayyadiin) for profit. Occasionally they moved between the coasts and hinterland fields which they cultivated for subsistence (Lancaster and Lancaster 2011, p. 35). Until the 1920s, the coastal belt population relied heavily on these occupations, particularly fishing and pearl diving. Trade nodes (often coexisting with Suqs/markets) were favourably located to exchange goods and products with the towns and cities in the Gulf, India, and East Africa. Indeed a broader mapping in time suggests a degree of 'historic cosmopolitanism' and 'urban life' as a feature of the sea-bound places in this region similar to many other port towns in the Arabian Gulf and the Red Sea area (Fuccaro 2014; Potter 2017).

Traditional architecture was a product-and-process of several interconnected factors (e.g., geographic location, economic activity and social status, and tribal affiliation), with all local prototypes adaptable to the challenges of the arid climate and scarcity of resources (Hawker 2015). Common dwelling prototypes varied from archetypical portable Bait Al Shaar (house of hair), Arish (palm frond fenced houses), Adobe and Adobe-stone walled houses (Hawker 2008; Heard-Bey 1997; Kay and Zandi 1991). Bait Al Shaar (tent) for the semi-nomad Bedouins was a tensile structure, fast to assemble, light-weight and portable dwelling prototype. The basic module was a long, narrow strip of heavy cloth woven from goat's hair or sheep's wool. The strips were then sewn together and raised up on tent poles. The tent space was divided by two or three long decorated curtains to provide privacy. Spaces were dichotomous divided into public side for men/al-shigg, and private/al-mahram for women (Dickson 1949; Saidel 2009). Contrary to orientalist stereotypes of passive Arab women, not only bedu women took part in domestic chores, they were also economic agents, with many venturing outside for trade and commerce. Women were also engaged in building activities-skilled at crafting, and were socially tasked with making, renewing, or pitching the tent (Dickson 1949, pp. 57-61). With this importance in societal practises, the female turf was allocated larger space than the male turf. The tent's overall size varied according to function, indicating its adaptability and flexibility in spatial arrangements (Amaireh 2011; Rosen and Saidel 2010).

Date-palm houses were called barasti, arish or khaimah according to particular coastal and desert areas in which these were located (Damlūji 2006; Heard-Bey 1997).
These residential blocks were typically single storied and minor in scale, with one or more rooms (cells) surrounded by a fence to provide privacy to the households. The perimeter fence served as a guideline for organizing the cells which strung out around open court/s. The visual axis would be cleverly diverted to avoid a direct look inside by an outsider, which was critical for privacy. This type of vernacular house was eco-friendly and adaptable to harsh climatic and social conditions. Spaces could expand without losing any of their essential qualities because each cell was self-contained. A house could add new cells or retract to single room ones depending upon life cycle or changes in the family structure (Hawker 2015). Traditionally people were not passive users/builders as Croll and Parkin point out, "People do not just adapt to environments, they make them, shaping them from both materials and the possibilities they see in the habitat and the surrounding life forms." (cited in Lancaster and Lancaster 2011, p. 12).

Before the 1950s, on the shore, built landscapes were much more complex and hybrid (Fig. 1). The coastal town was itself an interface between the hinterland and the maritime foreland-a confluence of diverse trade, tradition and social practice. The town contained three distinct morphological sectors; the seafront, the market area and the neighbourhood unit/residential quarters. However these sections were functionally connected to each other, much like a component in a network. Similar to what Nakib has observed in the case of pre-oil Kuwait port towns, urban life in these areas was marked by 'diversity and simultaneity' (multiple uses of the same space at any given time) (Al-Nakib 2020). The town was built on a pedestrian scale with streets' hierarchy secondary to the built forms. Houses were privately owned and its types catered to different social classes from wealthy merchants/traders from India and Persia, to native pearl divers or subsistence dependent semi-nomads who seasonally migrated from the hinterland. While houses for common people were of basic court types, of arish, groups of influential merchants hired local builders to construct complex, intricate and more substantial courtyard houses. Builders of the merchants houses leant on materials and techniques from the areas which had been linked to sea trades with current UAE since past centuries (Coles and Jackson 2007; Hawker 2008).

The common attributes of the neighbourhood/residential quarters were inward oriented courtyard houses, high walls and narrow streets. One case is much studied 'wind-tower' houses in the UAE. In this type of perimeter closed constructions, rooms were built up to the edges of the plot and opened up to a common space inside (open to sky court), ensuring thermal comfort, at the same time privacy and modesty for the women of the house-two 


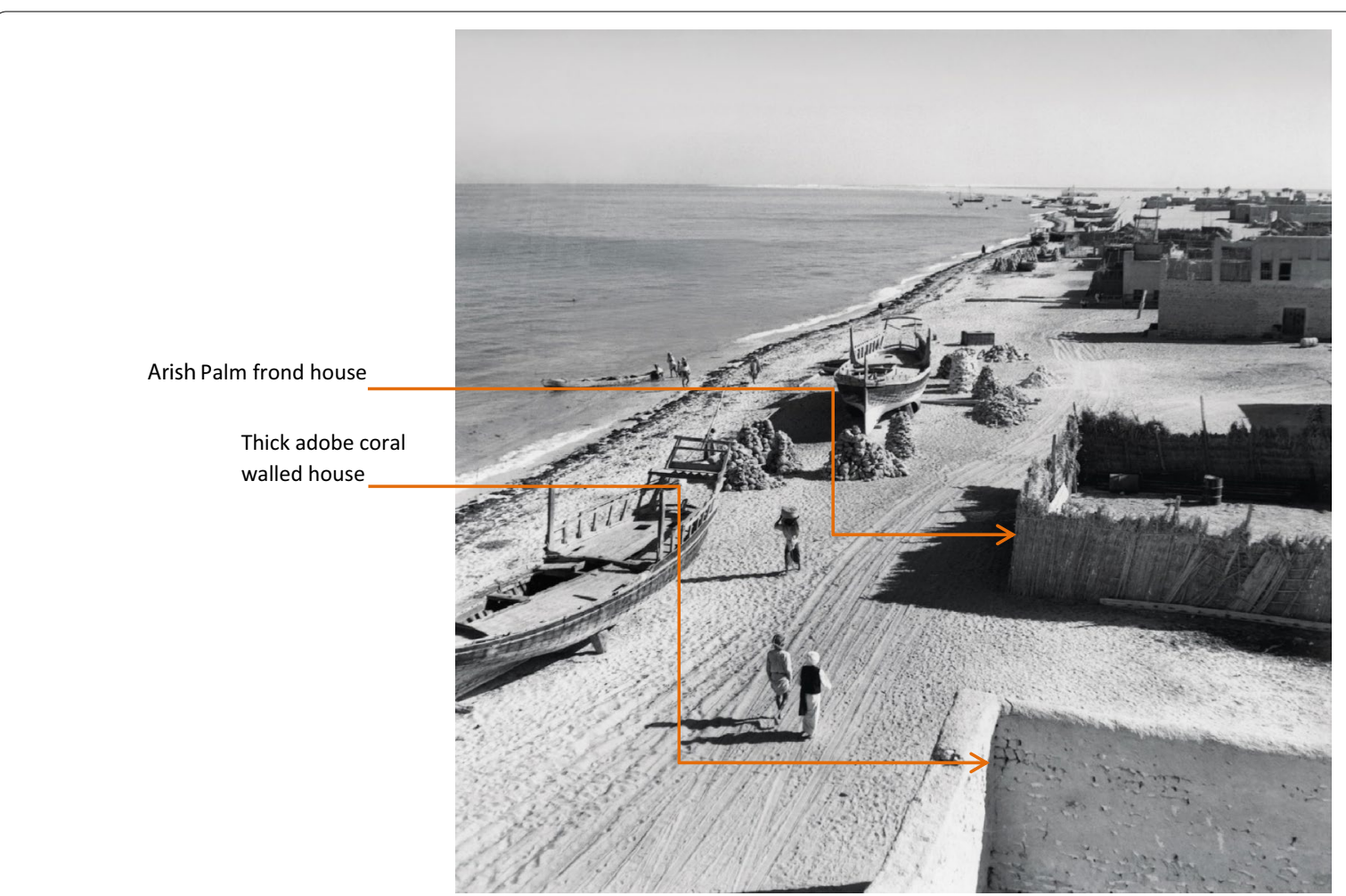

Fig. 1 Coastal house forms of the Abu Dhabi Corniche in 1953. Typical coastal houses were of introverted characteristics and varied in complexity. Source: Used with permission from National Archive UAE OBP plc

important concerns of largely Muslim communities (Bianca 2000; Othman et al. 2015). Courtyards (haouch) were the anchoring elements for any spatial articulation (Bianca 2000; Djamel Boussaa 2006; See layouts of windtower houses,Coles and Jackson 2007). In spatial areas male and female turf was noticeable in residential architecture, as it was in other areas of urban design in Arab-Islamic cities. Women had distinct female-majlis (social meeting room) built adjacent to a separate back entry (Djamel Boussaa 2006, p. 131; Coles and Jackson 2007). The male majlis, on the other hand, was located near the main entrance at the public front. It was a large reception hall or meeting and socialising room that was often the only one telling with decorated openings to the outside. (Kay and Zandi 1991, p. 11; Remali et al. 2016, p. 8). House itself was built to be experienced from inside. Thus inward court-centric transitional spatial features were evident, for example, iwan, an open-fronted room used as a sitting area facing a courtyard, and liwan or loggia (running verandah, separating the court/yard from the indoor spaces) (Fathy 1972; Kay and Zandi 1991). By design and planning, the houses in a quarter were internesting in a cellular pattern (Kiet 2011; Ragette 2003)-in character organic, additive and anticipatory, besides providing efficient functional solutions for privacy, scorching heat and glare. Furthermore, the narrow alleys 'sikka' between houses created informal walkways-spatial axes for pause and movement while providing walkers with shade from the sun and sand cover (Djamel Boussaa 2006; Fathy 1972). Each neighbourhood-freej/fereej/ fareej (a compact socially-charged neighbourhood) was resided in by groups, whose members often related to each other (Pallathucheril 2015, p. 99). Decisions about additions and alterations to the fereej were made by the locality. Like an accretive dwelling, a neighbourhood unit-(like fereej) similarly accrued over time as family lineage expanded, tailored to incremental needs, unselfconscious about its overall form, style and role in any history (Melhuish et al. 2014).

\section{Top-down planning, formalised grid and large scale urban systems (Post-oil era )}

Despite vibrant trade functions, coastal towns remained largely traditional until the 1950s. The 1960s saw the start of the development of modern cities throughout the Emirates. With the availability of vast oil wealth, a change in national leadership, and a global call for a new urbanity, Emirates changed dramatically in the 1970s (Abed and Hellyer 2001; Al-Zubaidi 2007; Damlūji 2006; Kay and Zandi 1991). These changes not only transformed 
everyday political and economic life of the society, but also the approaches and processes that underpinned social life (Al-Fahim 1998; Lancaster and Lancaster 2011). Yet the change from traditional coastal towns, places of first urban dynamics, to globalised cities did not happen meteorically in the post-oil era (contrary to popular accounts). Despite a flurry of international exchanges, discussions, and planning drafts on anticipatable urbanity, in the early 1960s (particularly between 1960-1966) urban development was unhurried. Launching of the UAE Federation in 1971 fast-tracked the urbanization drive as globalized plans fuelled massive growth in urban infrastructures.

National urgency for expedited construction in a 'design-build' sequence, paved the way for industrial building materials (prefabricated concrete, steel, glass) to fast replace traditional organic material inventory sourced locally. Planned roads began to spread out from densely populated coastal towns stretching across sparse settlements in the interior. Through efficient urban connectivity (which inevitably fast-paced automobile dependent urbanism and sprawls), utility services e.g., electricity, running water, sewage and air-conditioning systems were combined in buildings in the post-oil period. In less than a decade, citizens acquired the technological advancement that took the industrial West for more than two centuries to develop. Antithetical to the self-replicating inter-nesting compact coastal town tradition of Abu Dhabi, Dubai \& Sharjah, planners ushered in Western planning narratives of large scale systems, functional zoning, automobiles and urban sprawls and fragmented urban fabric. Built landscape changed-across the hinterland, oasis, and coast. Planning decisions also caused dispersal of the traditional pattern of clusters of kin-related residences. Cars also introduced a new visual and traversable scale to the urban landscape in the $70 \mathrm{~s}$, rearranging urban life through an auto-mobilized unit of 'time-space'.

Abu Dhabi's first master plan (unimplemented Harris Plan 1961/62), was proposed by British architect John R. Harris. Less referenced in scholarly accounts, Harris' plan included several layers of planning ideals. On one level, it proposed that the temporary buildings of arish and adobe be replaced in the emergent city, while on another, it resonated with strong conservation and regeneration agendas, as it listed seven elements of the current town/Abu Dhabi to be preserved-the palace, mosque, minaret, souq, coffee shop, narrow alleyways, and the house. At about the same time, Sir William Halcrow and Partners-a British consultancy and civil engineering firm was commissioned to design a master plan for Abu Dhabi. The blueprint purposefully pre-specified demolition acts, as it strongly advised that all buildings in the town, with the exception of the palace and a few other structures to be razed (Damlūji 2006, p. 17; Dempsey 2014; Hashim 2019).

In overview of Abu Dhabi's late 1960s development after Sheikh Zayed's, (revered as Father of the Nation), accession to power in 1966, three key ones are the ARABICON Plan (1967), Takahashi's Plan (1968) and Makhlouf's Plan (1968) (Hashim, 2019; Kyriazis et al. 2017). In each of these blue prints, housing for the emergent nationals was considered as important urban assemblages. However these three blueprints' were not blank slate and stand-alone developments as each developed out of its predecessors' legacies. For example earlier (1960 to 1966) Harris Plan 61/62 and Halcrow Plan records, exhibit clustered residential/house layouts of different configurations and schemes with emphasis on neighbourhood unit concepts. British architect John Elliott, who had extensive Scandinavian planning experience, also worked on national housing prototypes at ARABICON in close collaboration with Sheikh Zayed. As translation proved difficult, out of urgency for an Arab planner with Arab-Islamic understanding, the Sheikh later appointed Egyptian Architect and planner Abdelrahman Makhlouf to carry out the proposed plan for Halcrow for Abu Dhabi. Designed housing based on neighbourhood concept was a high point of Makhlouf's contribution. But clearly national housing trend evolved partly from ARABICON and Takahashi plans and their precursors, which Makhlouf inherited. In this way, the notion of prototype housing as 'National house' thus (re) surfaced as part urban-planning agenda while Makhlouf was in charge (1968-76) (Duncan and Tomic 2016; Reisz 2013). From the 1970s onward, transnational design concepts and technology spurred by the political utopia of a new nation-state intertwined with tribal values, created a complex paradigm of urban housing in the UAE.

\section{Non-iconic modernity: housing in the late 1960s-70s}

While top-down planning notions roamed and evolved on the one hand, and older building legacies-of the coast or the hinterland-were erased on the other, changes and continuities persisted at many layers on localized domestic forms. The traditional date-palm fenced house/arish underwent material make-over in the seventies. When imported materials became widely available in the 1970s, the traditional date-palm fenced house/arish underwent a material makeover. While industrial building materials replaced organic materials like palm fronds, the spatial order of traditional fenced houses was preserved, with a loose arrangement of inward facing rooms adjacent to the protective fences. These retrofitted houses were popularly known as Arabic Houses (Al-Mansoori 1997) (Fig. 2). Since this self-managed type allowed for 


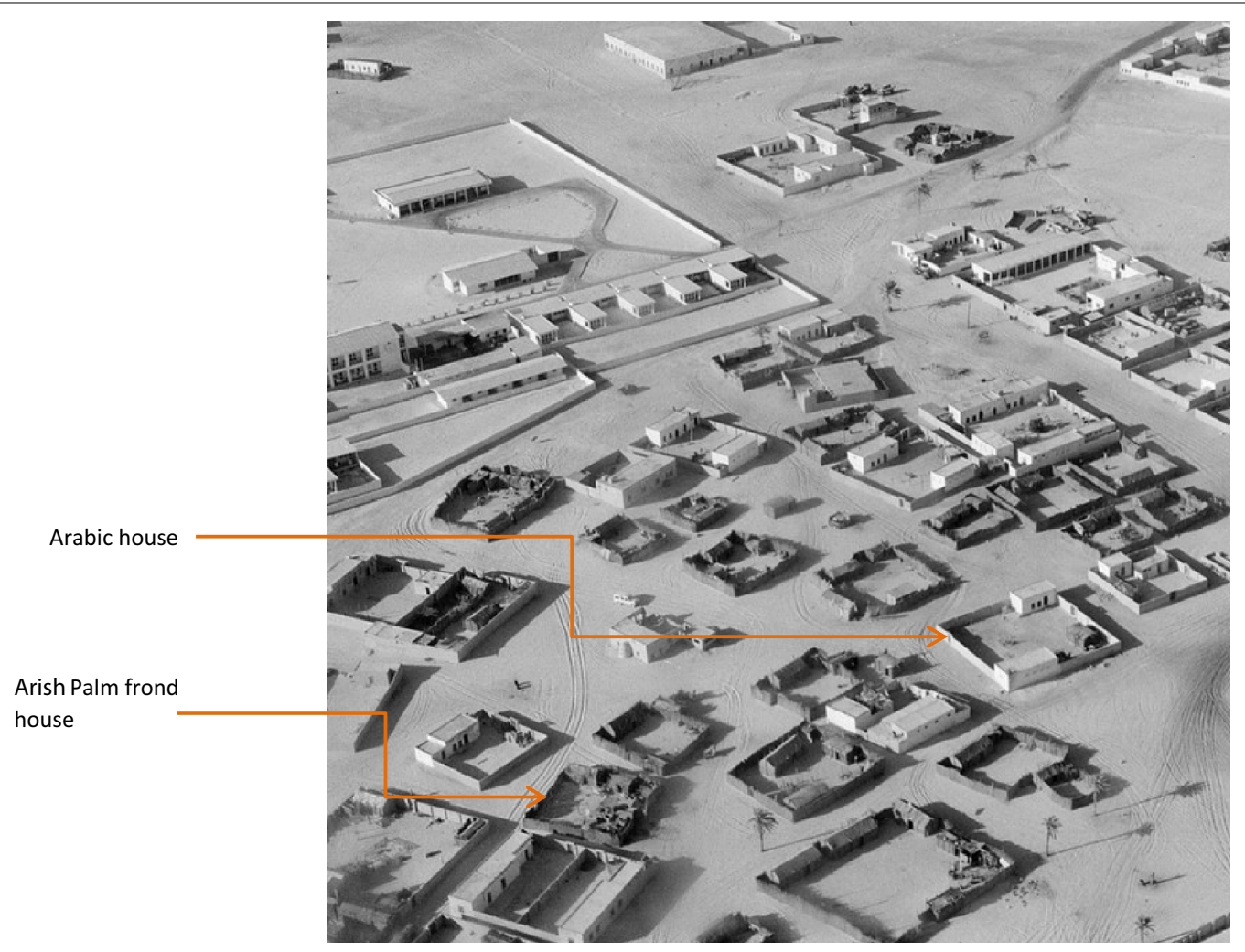

Fig. 2 Aerial view of the island of Abu Dhabi in the early 1960s. Photo shows palm-frond/Arish and Arabic houses. These house forms had add-on gradual features. Source: Used with permission from BP Archive, University of Warwick @BP plc

modular extension, local people frequently added rooms to their original date-palm houses based on their affordability, until eventually all old rooms were replaced with masonry bearing walls with 'cement-sand'. The external and internal walls were plastered and painted so that facade had a smooth industrial surface. This bottomup design (user generated type) where the house actually grew with the residents evaded any imposed spatial incongruity as users were directly involved in the design and decisions.

However, a national interest drove the most significant change in urban house form-from informal to formal house type. The concept of mass urban housing as Emirati National Homes dates back to the late 1960s. Sheikh Zayed Nahyan established a low-cost housing programme in Abu Dhabi in 1966, shortly after becoming ruler. This programe showcased concrete houses equipped with electricity, sewage disposal and running water (Heard-Bey 1982; Sadik and Snavely 1972). From $\mathrm{Abu}$ Dhabi, the housing programme grew to include separate but similar schemes in other Emirates. Sharjah established social housing programmes in the early seventies similar to the Abu Dhabi national programme.
Indeed, since 1966, concepts for a new type of urban model housing for the tribal population have been trialled by foreign consultants in very close collaboration with Sheikh Zayed. The Sheikh's intention was partly political as transient lifestyle of sparsely settled tribes made it difficult for the region to achieve the desired modernization. There was a pressing need for a new urban paradigm that would be compatible with a newly emerging wealthy nation while also consolidating a tribal population who would adopt new identities as 'nationals' Zayed hired a number of international designers and consultants, including ARABICONs young Elliott, who moved to Abu Dhabi in 1967. His key responsibility was to design national housing with one-on-one consultation with Zayed. Other multi-national experts and consultants soon joined the loops. In 1974, architect Wolfgang Braun was summoned from Germany, along with architect Peter Säckl, engineer Juergen Monnerjahn, and a selected construction team. They were tasked with constructing a prefabricated experimental prototype house in the desert near Al Ain, an oasis town. (Leech 2016; Wimsatt 2010). These model houses featured modern industrial look and spatial components. With modest scale and modernist modest schemes, they were stylistically 


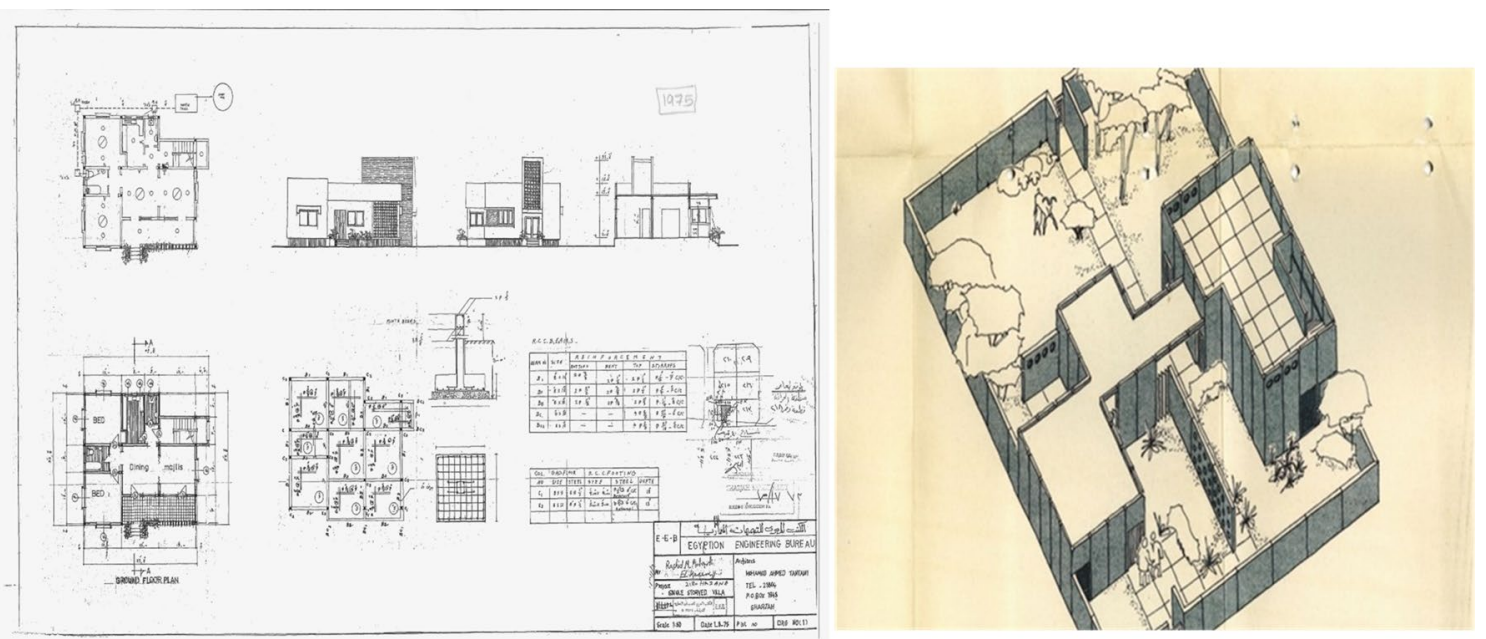

Fig. 3 On Left, example of a consolidated typology in 1975, designed by an Egyptian Engineering firm. Source: Emirati architect Moza Mohamed Rashid Saeed Abdalla. On right: Example of accretive type in 1974 on the right by Wolfgang Braun and architect Peter Säckl

distinct from the archetypal opulent residential villas that are now common throughout the UAE. However, in the 1970s, Western architects frequently advertised these basic perimeter-closed house types as "villas," probably to conjure up exclusive proprietorship of a stand-alone residence.

The late 1960s and 1970s saw transnational flow and exchange of urban discourses in the oil-rich Gulf countries, instilling a sense of social ethics in the UAE urbanism. Rather intriguingly, the national vision of free houses for citizens or new tribal housing somewhat converged with notions of social housing (a strong sense of social duty in that architecture should improve the living conditions of the masses) at the time sweeping across the mass housing paradigm in the West (Urban 2013). The Sheikh and the transnational consultants and planners were driven to a social equality framework for the tribes, so that they would not be differentiated based on materiality and would have equal access to modern facilities and opportunities. As a result, prefabricated items and other industrial techniques were quickly incorporated in the UAE's first post-oil urban housing designs. The minimalistic building façade followed the structure and purpose of the building, whereas adornment was secondary to form in dwelling prototypes. Indeed if the key features in the modernist design include function, progress, antihistoricism and social morality these principles (Curtis 1996; Frampton and Futagawa 1983; Greenhalgh 1990) are found in many of the key drafts or realisations of the first national urban house prototypes in the UAE. Similar efforts toward modernist efforts in housing and broad scale city planning could also be seen around the same time in independent states in Middle East and North Africa.

The initial provision was a single storey house in a perimeter closed site. The built-up area of these first housing units ranged approximately from 90 to 120 square metres. The housing unit was built on a 400 square metres plot $(20 \mathrm{~m} \times 20 \mathrm{~m})$ or slight variations of $576 \mathrm{sq}$ meters $(24 \mathrm{~m} \times 24 \mathrm{~m})$, with a 3 -m high surrounding fence (Al-Mansoori 1997; Leech 2016; Wimsatt 2010). Each house consisted of two bedrooms, living room/majlis, kitchen, bathroom, shower and a courtyard. Roof terrace (flat roof, thus space optimized) was reclaimed as an additional sleeping floor at night (a feature typical in traditional Arab town houses in the Gulf). A date-store was also included in the house programme to meet Zayed's personal brief: to design a housing typology for Bedouins that would respect their traditions while facilitating them in settling in urban areas. The building structure was modern and made of long-lasting/ permanent materials. The overall construction process was transnational, with building materials imported from Japan, Germany, and the United Kingdom, as well as labour from India (Al-Mansouri 1997, P.70). Although these sponsored urban house forms were formally varied in design, few modern types were composite-accretive (with additive blocks) with loosely spaced open green spaces/courts around which the basic domestic zones were grouped. Spatial arrangement of this type facilitated social living, communication as well as privacy. In other examples, the house was clearly consolidated into a single core/compact form (Figs. 3, 4). The external-oriented compact forms were designed with an integrated kitchen and services arranged in a Western consolidated 


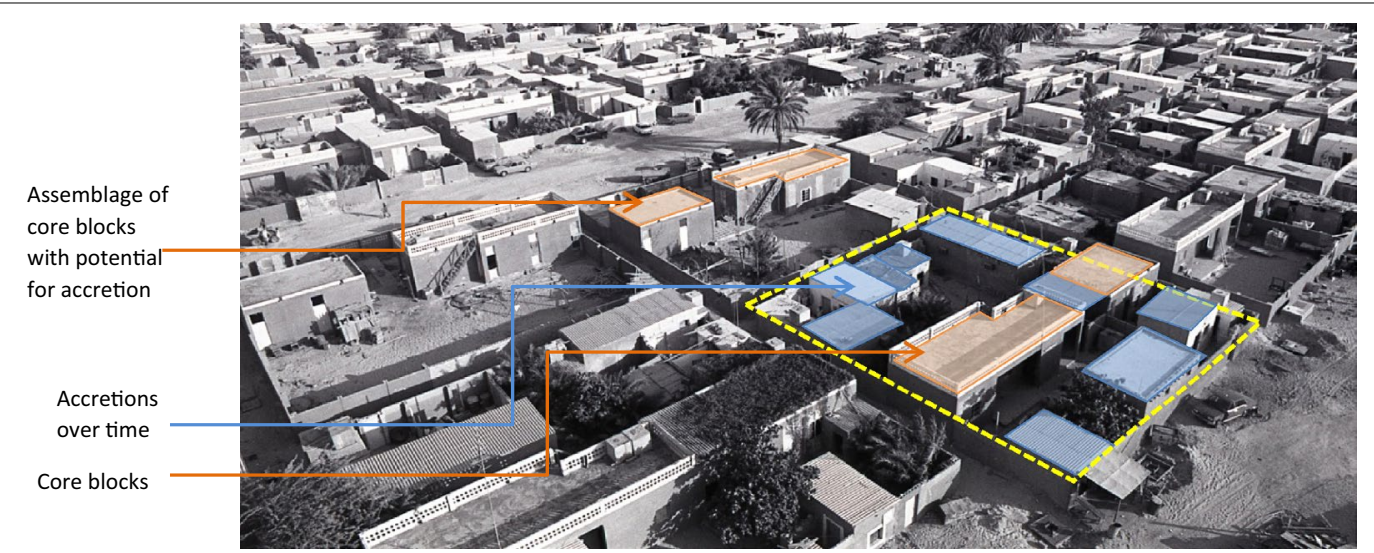

Fig. 4 Composite and accretive sha'abi Houses, Abu Dhabi in 1974. Note the potentialities of spatial accretion over time. Photo: Radboud Universiteit $\odot$ Gerard Klijn/Katholiek Documentatie Centrum Nijmegen

apartment style. From the standpoint of nation-building, these houses appeared progressive and promising, comparable to housing styles associated with modernist schemes of Western progressing nations.

However for the hinterland pastoral nomads who basically leapfrogged to settled urban lifestyles and new urban-spatial orders, providing appropriate housing was anything but challenging. Damlüji perceptively recounts:

One of the reasons for difficulties in adjusting to the urban environment is that many people come to the city from nomadic settlements, where shelters are no more than a du'un or 'arish made out of sa'f al nakhil (woven panels of palm fronds), or sometimes a tent with a awsh around it, which were never grouped close together (Damlüji, 2006).

Bedouins had mixed reactions to these basic, unembellished, initial model houses who received these house as 'gifts (Fig. 5). While some residents welcomed changes in house styles as a means of assimilating into a modern wealthy society, few also raised cultural concerns about the predominantly Western house models, particularly in regards to space utilization, purpose, scale, personal expressions, and privacy. In addition comfort in a 'cement- house' (as it was originally dubbed)-a climatic context where the temperature can go as high as 50 degree Celsius-was also a disconcerting issue.

Kurokawa's narrative (Bedouins Can't Live in California-style Housing) is evocative of the 'designer vs tribal user' dilemma as well as the climatic contradiction, as he visited a consolidated type.

So I went with the government leader to inspect the housing built by the American architect. When we arrived at the site, a strange scene greeted by eyes. The housing was two-story concrete American-style residences, the kind one might encounter in California. Each unit was all completely air-conditioned and had an attached garage. And there they stood, in a line, in the middle of the Arabian desert. But as we approached I saw that the Bedouins had set up their tents next to the housing and they had placed their sheep and livestock feed inside the units.

In the seventies, the design of urban house forms included two important considerations: family size and local climate. House size was enlarged to accommodate two to three bedrooms. Climatic comfort prevailed as a prerequisite for house design. Housing planning policy particularly pushed for buildings that would protect residents from the summer heat and winter cold (Al-Mansoori 1997). Durability factor of construction was also revisited after some earlier built ups collapsed due to structural instability. Between early 1970s to early 1990s,

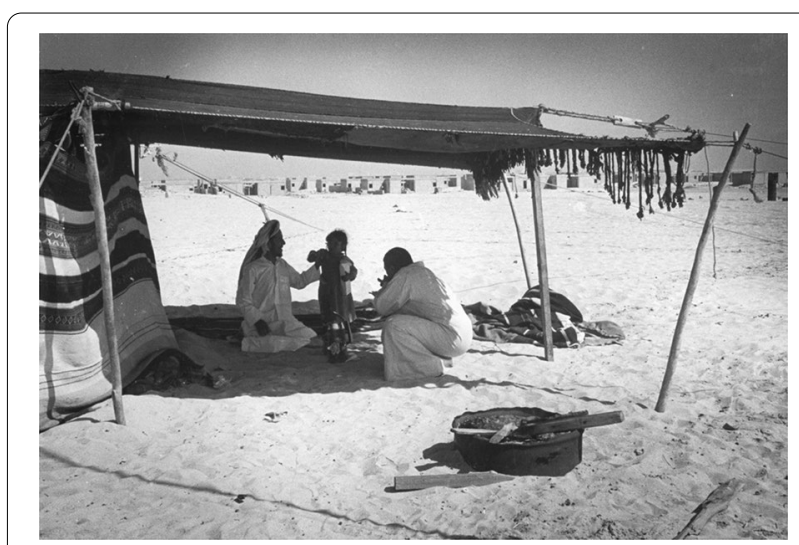

Fig. 5 A traditional tent bait al shaar in the foreground; in the backdrop a sha'abi housing under construction in 1974. Photo: ( Gerard Klijn/Katholiek Documentatie Centrum Nijmegen 
the standard of the low-cost house changed several times. The modest scale and the compact formality of the house form received adverse reviews as locals continued to live in extended families and kept adding on rooms/blocks as required under changed circumstances. As a result, the built-up area in succeeding prototype increased four times while the construction cost significantly multiplied. Some of the older sha'biyaa prototypes were wiped out for example in Abu Dhabi by the late $70 \mathrm{~s}$ most of these houses were demolished, as globalised infrastructural plan and a development and land-use scheme were conceived (Podcast Leech 2016). Few however survived, fortuitously for regeneration and conservation lessons. A number of them are currently rented out to lowwaged expat workers. A section of Emiratis also occupies a number of these surviving structures as adapted residences. These non-spectacular urban forms recently found recharged meanings through an exhibition at UAE National Pavilion at the 15th International Architecture Exhibition of la Biennale di Venezia (Venice Biennale). The Biennale 2016 unveils that in city fringes and also in city centres some of these forms have interestingly survived. According to Yasser Elsheshtawy, Curator of the National Pavilion of the United Arab Emirates (UAE) at the Biennale di Venezia, these industrially assembled urban forms are adaptive, incremental, and leave the option open for personalization in architectural elements and spaces, suggesting their flexible characteristic and user friendliness (Kumar 2016). It is interesting to recap that while modern and reproduced large-scale planning schemes had a corrosive effect on the constructed and the natural landscapes of the 1960s and 1970s, smallscale residential projects-at least a portion of themsustained the goodwill of social designs.

\section{The quandary of sustainability (Estidama)}

Stand-alone, low-rise (two-story) villas marketed as "Houses for the Nation" are currently the most dominant form of national housing in the UAE. The villa is clearly more technologically advanced now, with features such as hot water, a green-star-rated air conditioner, and fiber optic networks. There is also a noticeable change from the 1960s on the exterior façade. While there are many different stylized facade styles to choose from, the most popular are heritage or seemingly post-modern ones. Despite the glare and heat, large areas of glazing are cut into the exteriors and framed by shallow arches, pilasters, or pseudo-historical elements. Wrapping has also changed from basic functional industrial materials to sleek external cladding with marble, face brick and ceramic tiles etc. Indeed while the façade has become an icon and technology has fast-tracked since the $70 \mathrm{~s}$, the current house appears to have lost its meek place-identity and turned unresponsive to the natural environment.

UAE is ranked as one of the feeblest performers on the sustainability side. As Daniel Moshashai has pointed that by the time Vision 2021 (national target which prioritizes among other points: cohesive society and preserved identity as well as sustainability) was drafted, the federation was ranked second in the world in terms of $\mathrm{CO}_{2}$ emissions per capita (Moshashai 2018). Overall, data showed that an Emirati consumed twice as much energy as an American and four times as much water as a Briton.

Although sustainable urban frameworks are still in their early stages in the UAE, the Abu Dhabi government introduced Estidama (Arabic for sustainability) in 2008. Estidama (some-what analogous to LEED) lists building design methodology and guidelines that ensure sustainable construction. It is part of the Plan Abu Dhabi 2030 urban master plan that addresses sustainability as a core principle of design. The guidelines are also first in the Middle East, tailored to meet the region's environmental, economic, social and cultural requirements. Pearl Villa Rating System (PVRS) - a green building rating system is employed by Estidama which promotes sustainable villas with a minimum rating of 2 at the desired level (UPC 2010). ${ }^{1}$ To support the implementation of the plans and fulfil its mandates UPC also endorses Complete Sustainable Communities (CSC) initiative (WAM 2015). It is a rigorous set of policies, and planners' manuals for adaptable communities to meet the diverse needs of present and future residents, visitors, and enterprises, while also furthering society by offering well-connected, secure, and sustainable housing options, public spaces and amenities. Policies also extend to particular urban ensembles such as developing traditional Emirati neighbourhoods (a high priority for Estidama). UPC for example advocates the freej/fareej system (conceivably as a push for heritage reconstruction), with neighbourhoods of clusters of homes placed around a central courtyard or outdoor recreational space with particular highlight on the key elements: the courtyard house, sikka (narrow alleyways), and barahaat (intimate public spaces), as well as large gathering spaces or meyadeen (Hashim 2019; UPC 2011). However one could argue that these efforts resulted merely in neighbourhood planning catalogues and brochures. In contemporary urbanism there are also strong promotions around walkable communities as well as 'liveable neighbourhoods' with mix of residences reminiscent of older urban traditions before the 1950s.

\footnotetext{
${ }^{1}$ However, PVRS does not only address environmental factors; it offers manuals that have direct implications for the shape and size of the house; for example, the maximum size of a villa is currently allowed to be a whopping $2000 \mathrm{~m}^{2}$ (conditioned space).
} 
As Emirati scholar Hashim points out that although Estidama, has merit in concept but implementation has proven to be difficult (Hashim 2019, p. 187). Noting what is being actually built now in the urban sprawls next to huge shopping malls and mega parking lots, one could argue that if enough attention is paid to socially meaningful and energy-efficient layouts at any scale-either residential unit or planned neighbourhood.

These precedents are seemingly antithetical to ecologically and socially sensible past forms and features. House types have radically transformed from traditional houses which once advocated green/passive design elements or features such as open to sky courts, small windows, native vegetation, climate-responsive orientation and spatial layout. On the other hand urban housing is now factored to urban sprawls, exterior oriented house type with huge glazing, perimeter garden, sealed atrium, road facing orientation, high-energy consuming air-conditioning systems etc (Winter 2016). ${ }^{2}$ Due to use of airconditioner, hermetically sealed spaces have significantly eroded transitional spaces, for instance, liwan, iwan and loggia. Environmental transactions are thus restricted, reduced and stripped of potentiality. Other than a few 'smart' infrastructure or technical features (e.g., solar panels, solar windows, smart security devices) residential designs rarely incorporate any pioneering, sustainable/ green environmental solutions.

In upshot villa's parameters are equally at odds with its predecessors as well as progressive Western urban models of high-density living, compact city models (antithetical to urban sprawls), that promote environmental benefits, sociability, community-based neighbourhoods, walkability, and reduced pollution. More specifically, the swappable image-centric house has now nipped home's process-reality. Besides degradation of environmental sustainability, this loss of cultural sustainability, can be framed within current sustainability discourses. Khan (1995), for example, has argued that the main menace to sustainable development comes from the cultural front, notably the 'culture of maxima' promoted and pushed by the West. Similarly Thaman (2002) asserts that for development to be sustainable, it must be rooted in people's cultures; and indeed culture is the foundation of sustainable development. Drawing upon socio-cultural sustainability, Chiu points that sustainable housing should not be merely about meeting basic needs, but should also improve the liveability of the living environment, both internal and external (Chiu, 2004).

\footnotetext{
${ }^{2}$ Water consumption per capita in the UAE is among the highest in the world. Since the groundwater aquifers have been dwindling it now depends on energy intensive desalination. UAE's carbon emissions are also the highest in the world (with three-quarters of energy consumption reliant on air-conditioning).
}

\section{User driven changes: continuities and contingencies}

The stand-alone villa, its commodity form as well as its iconic depiction framed by visually branded facades (elevation as frontispiece) can somewhat be countered by a user driven spatial re-focus. This plausibility sets the ground for an overarching question: is today's iconic Emirati villa an antithesis to its precursors (a disconnected precedent, therefore) or is it an urban hybrid resilient house form that has changed but still bears the hallmarks of its predecessors? To venture an answer, in this section we reconsider the past simultaneously with the present by shifting the focus from top-down policies and agents to everyday protagonists, the Emirati users and their capacity to retort and adapt. In the process we map what Emiratis change or build after they move into their houses (Figs. $6 \& 7$ ).

Before delving into the specifics of user-generated spatial accretions and assemblages, it might be helpful to interpolate a few cross-cultural theoretical directions. This is done to situate the villa case in a range of bottomup urban development discourses and de-exceptionalize it from the Gulf context. These lines of cross-geographical works charter that if built form and environment fail to reconcile behavioural requirements, users will be inclined to correct the problem through such measures as particular uses, construction and renovation (Kent 1993; Rapoport and El Sayegh 2005; Turner and Fichter 1972; Turner 1976). Just as Lawrence (1987) points, planning decisions can not strictly decide on the form of urban houses. Indeed uncertainty and contingency impact buildings. Circumstances invariably intervene to upset the best-laid plans-at every stage in the process, from design through construction to occupancy, as Till (2009) has asserted. Till and Hill further allude (Hill 1998, 2003; Till 2009) that users/residents and their creative adhoc approaches can potentially inform future design. Several seminal studies further address the significance of context, contingencies and lifestyle based choices, in which designed precedent resides in a social and cultural locale (King 2003; Rapoport 1977).

User-generated bottom-up spatial accretions in Sharjah and Abu Dhabi coalesce with these theoretical directions. When the iconic core house form (Villa form) fails to reconcile behavioural needs, Emirati users correct the problems through specific uses, adaptation, and renovation. Although accretion studies have received little attention in academic publications, a decade of tracking of neighbourhood-wide accretions reveals a similarly evolving and anticipatory pattern of the villa (Figs. 8, 9). Interestingly, while majlis, kitchen, and other spaces are included in the core form's design layout, they are recreated and reformed in separate structures (as accretions) with added privacy, accessibility and zoning considerations. 

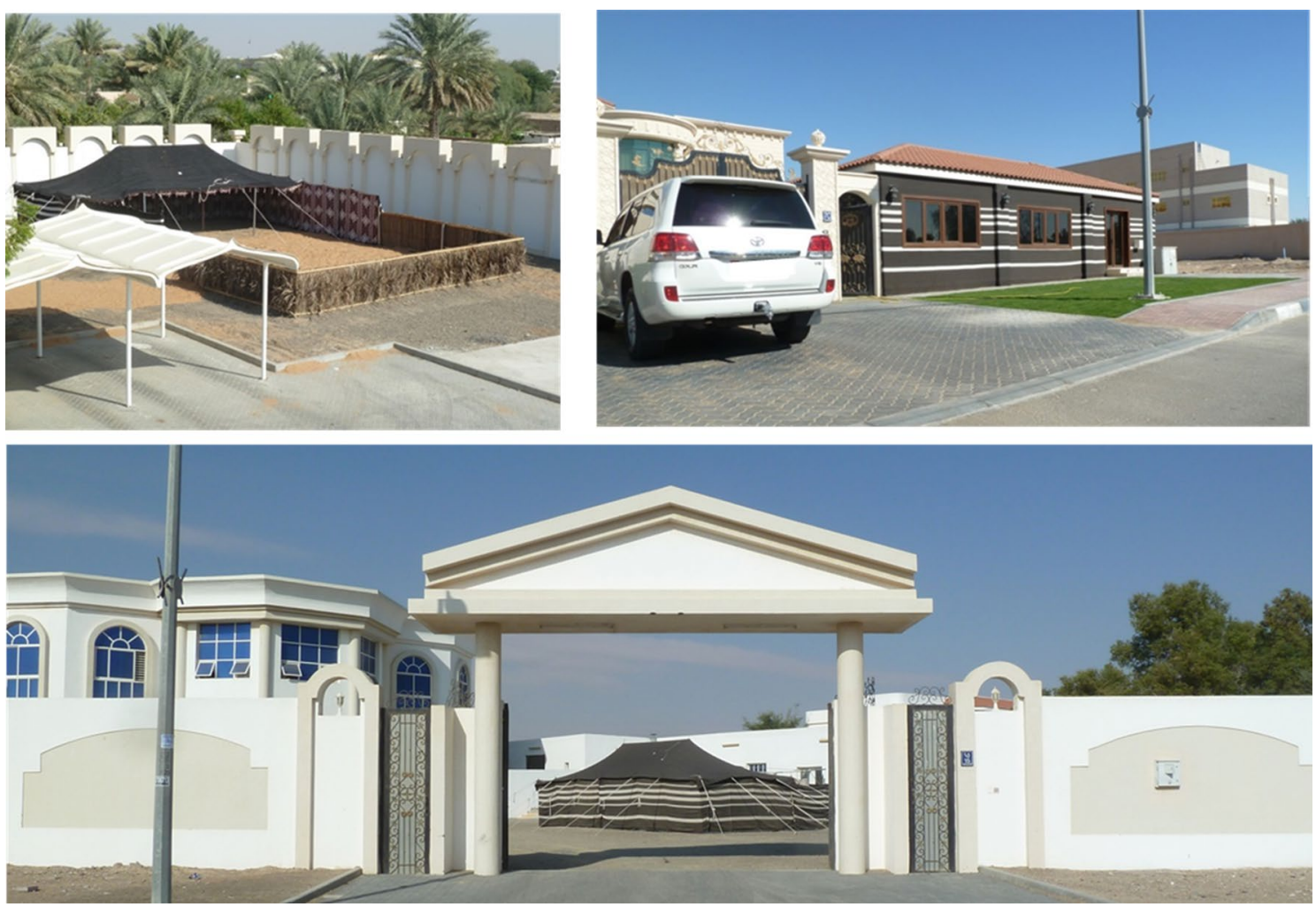

Fig. 6 Spatial accretions in contemporary villas. Left: An ad-hoc tent Majlis, reminiscent of bait al shaar, inside the perimeter compound of an Emirati villa. Right: A perimeter-built neo-majlish facing the road. Note the permanent structure of Majlis is cladded with fabric in distinctive black and white stripes. Note the majlis can be entered directly from the on street parking area. Bottom: Perimeter enclosed villa compound with core villa on left and the ad-hoc tent Majlis and service blocks on the right. Photos: Authors collection 2008-16 Al Ain

Villa's domestic spaces are consumed in a variety of quotidian ways, sometimes through creative residents 'negotiations over a stretch of time. Accretions around consolidated villa form continue in the process on-going design, construction and long after it is formally produced e.g., the service zone, ad-hoc majlis are two examples. Construction of a large kitchen detached from the stand-alone core house is very common practice in a contemporary villa, Part of this occurrence can be explained by the Emirati women's current role in the kitchen. Most Emirati kitchens rely on housemaids or male cooks from India, Nepal, Pakistan, Bangladesh, Southeast Asia or Africa (or simply 'outsiders' from whom family privacy is sought). Privacy remains an important concern in urban $\operatorname{lives}^{3}$ (an issue that prevails across religion and culture).

\footnotetext{
${ }^{3}$ Readers may also note that currently a higher percentage of Emirati women than males are educated and are active in the workforce or placed in training and higher education. Women's literacy is 91 per cent and more women than men prefer to enrol at universities. One may also note that women in the UAE enjoy the same constitutional rights as men (Al Otaiba 2017; UAE Government 2018)
}

As a consequence, domestic zoning is user-deflected to disentangle the 'outsider-insider' conundrum of coinhabitants. This is also perhaps to tackle socio-psychological needs of the residents given that 'Olfactory privacy' plays an important role in the control of smells or odours produced in kitchens and to avert them from dispersing to zones where guests are entertained. This third notion of privacy (besides visual and acoustic) and its needs have been insightfully discussed in Muslim homes by a number of authors (Sobh and Belk 2011; Sobh et al. 2013).

Another observed circumstances driven spatial conundrum in Emirati house is an informal majlis-an addendum to the villa core house. This complementary assembly is erected either as a tensile tent, or a rigid pitched or flat-roofed construction (wrapped in tentlike simulated façade pattern), and stands as a spatial appendage in or outside the perimeter wall. There is a tendency to embellish these minute to modest structures with monochromatic pattern of distinctive black and white imitative stripes (as in bait al shaar)and screens of geometrically patterned colourful decorative fabric 


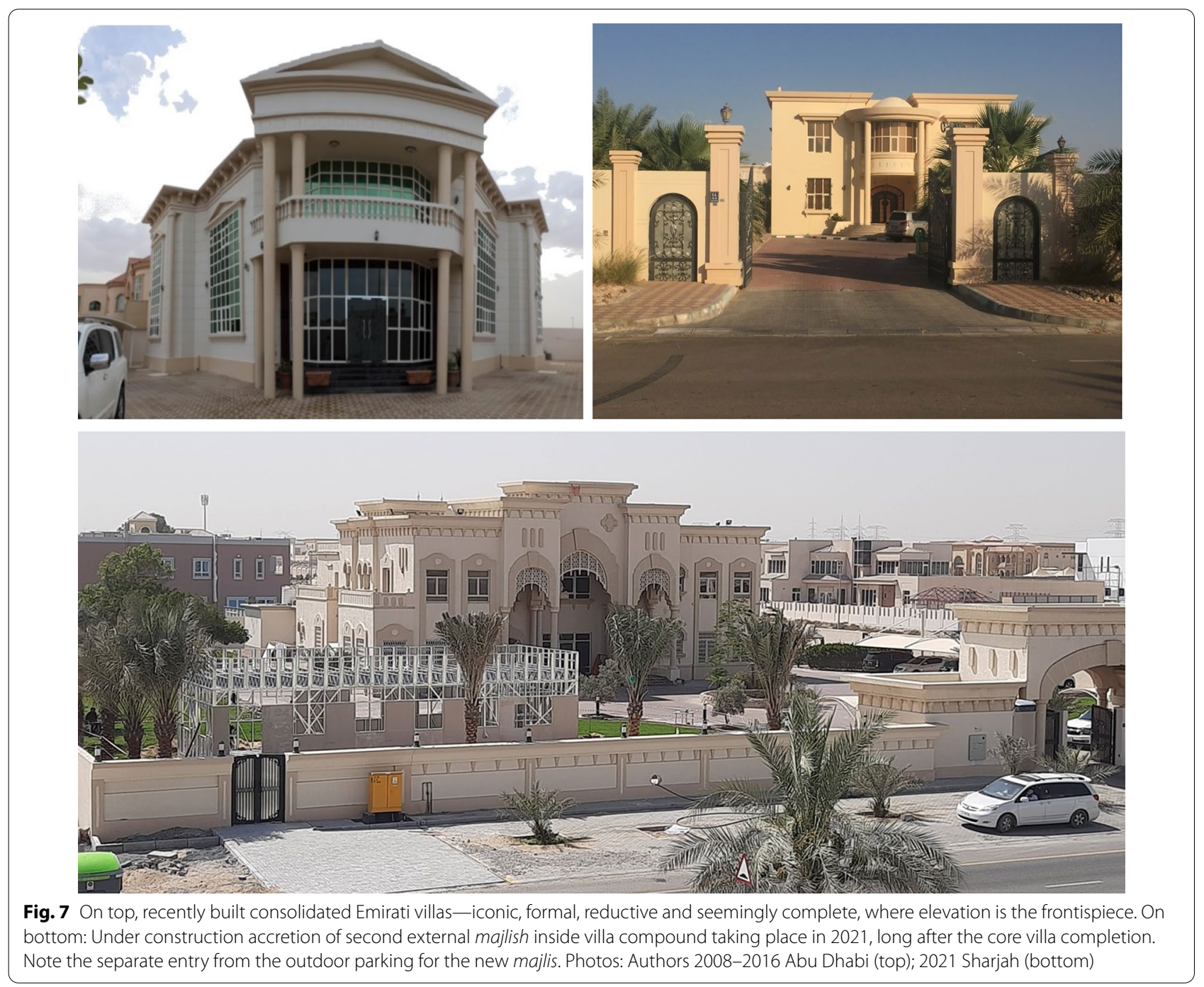

(like popular patterns used traditionally in fabric). With tea and traditional coffee making accessories, this majlis are often furnished with traditional Arab Tekay (Arabic cushions) and Doshak (floor covering) (Salem 2009; Sobh et al. 2013). Yet technological embellishment is also evident, with air-conditioners, Smart TVs and videoentertainment accessories. The Emiratis' appropriated space is a reconciled space-a hybrid space in which the dialectical relations of commodity, globalizing elements, technology, and tradition are always evolving. Majlis in different forms and scales also occupy a more permanent place in the design layouts. In addition or alternative to the modest tent, residents often prefer to build a substantial majlis detached from the core house, sometimes a complete wing with dining and kitchen. Readers may also note that, given Emirati women's resilient role in modern society, female majlis is still maintained in design programs, with sustained consideration for indirect access to the female majlsh. On the other hand, male majlis continues to occupy the public front.

\section{In retrospect: concluding notes}

The mapping of context and contingent driven pre-oil and post-oil built precedents and their interconnection can help to refine the emerging urban regeneration agendas in the UAE. Our conclusions point to the importance of pre-oil architectural legacies which are of living relevance. These legacies inform and explain the present Emirati user driven ad hoc changes in the national housing situation in a meaningful way. In the process Emirati users' decisions and spatial activity patterns, point to corrective directions for architecture, housing and urban design, and emergent cultural identity.

The pre-oil coastal landscapes, where the first town activities emerged, demonstrate diversity as well as simultaneity of various informal dwelling forms, layouts, 


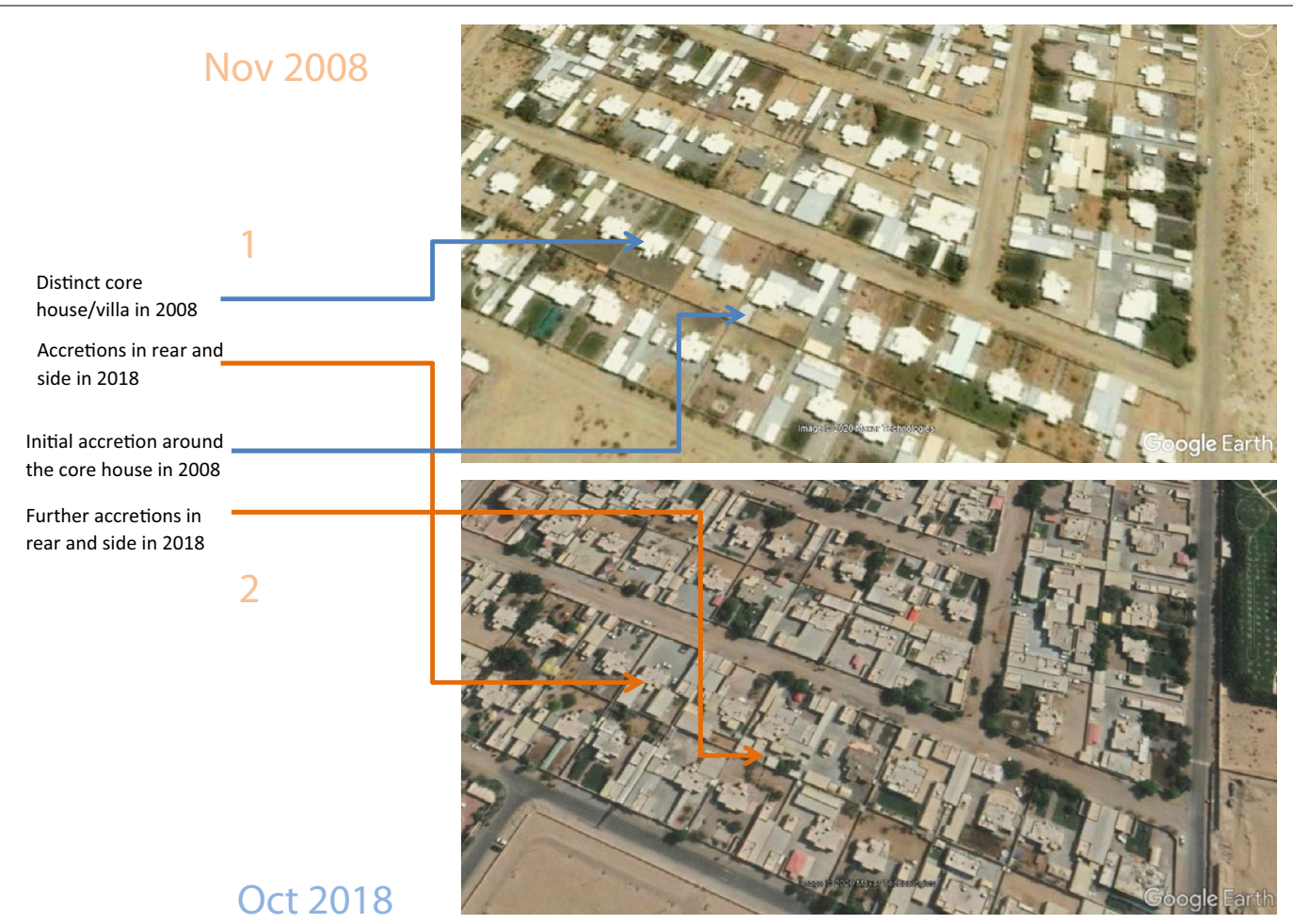

Fig. 8 A decade of user driven accretions of Emirati villas in Al Noaf, Sharjah. Image credit: Google Earth Pro 2020. Nov 2008 \& Oct 2018
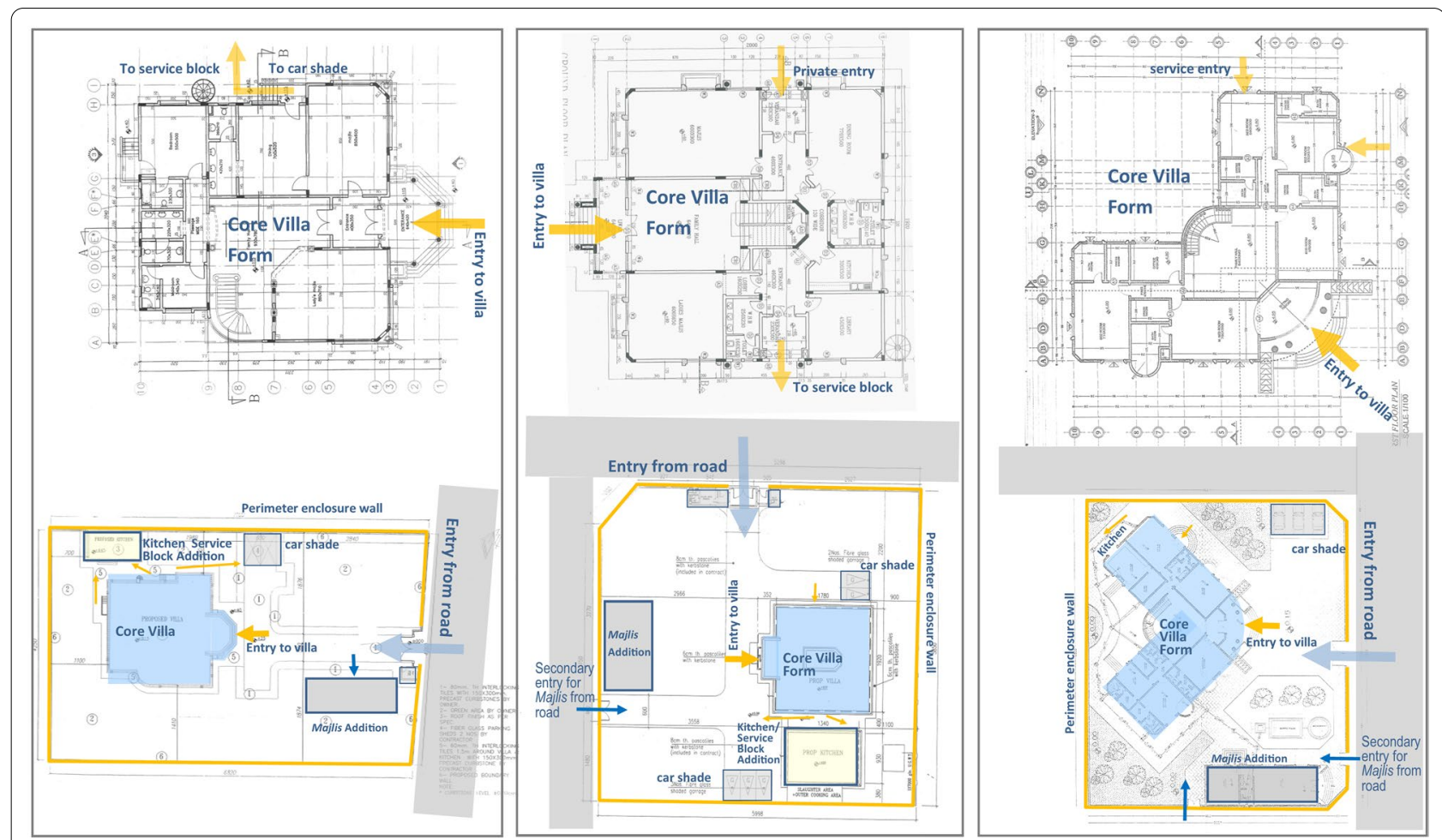

Fig. 9 Three examples of Emirati villa. Core house and initial spatial accretions planned in design stage within perimeter enclosed villa, in site plan and villa plan. Source: Authors collection 2008-16 
spaces, and building techniques. By way of adaptations, spatial accretions, incremental built-ups, user driven pre-oil traditional dwelling forms were socially congruent and evocative of spatial-ephemerality. Deeper livedin social aspects were also distinctive features of the larger spatial units such as neighbourhood/freez. Besides, these settings were environmentally sustainable as they sensibly utilized energy thrift passive measures to combat extreme arid climate through local materials and contextual design details. Although International Style and transnational exchanges of urban discourses dominated UAE's planning and housing practise in the postoil 1960s-1970s, there was also hybrid housing trials/ experimentation to coalesce with the traditional past. As a result, sha'biyaa (first formal housing types for the nationals), featured both consolidated external oriented modern urban house types, as well as hybrid spatially accretive ones that fostered and continued with nuanced spatial legacies. It is worth noting that while oil-wealth brought institutional and commodity driven fundamental changes to the local landscape and social fabric of the UAE, there were also meaningful connections to the past that were largely overlooked in received narratives.

Fast-tracked into the twenty-first century, contemporary stand-alone villas are packaged, branded, and delivered as a marketable commodity. With sustainability concerns surfacing merely as branding, a snapshot of a villa points to it as a swappable image-centric house that is antithetical to the reality of home or process aspect of living. On the other hand, as evidenced by spatial accretions and patterns of change (the service zone, hybrid neo-majlis, diversion turns to secure female majlis privacy), contingency by UAE citizenusers elucidates a retrospection of social and cultural agendas. Indeed the newest modified plans or constructions for residential villas recall principles that were well established in the pre-oil built-ups. This finding vindicates past and present dialogue and users' adaptations as a way to rethink the current architecture, housing and planning agenda in the UAE. A stronger discursive relationship between top-down planning and Emiratis' user-driven, residential forms (i.e. crossscalar discussion) is thus needed to understand cultural resilience- outside dominant or received view of an iconic space or form. By broadening the interdisciplinary understanding of the evolving spatial needs of Emirati houses and the forces that form them, the study thus clears the way for more in-depth studies. This is aimed at creating more inclusive Emirati dwellings as part of socially and environmentally sustainable design and urban regeneration.

\section{Acknowledgements}

Journalists and contributors to the daily newspaper The National, particularly Nick Leech and James Langton, have been helpful in directing to source materials. We are also thankful to Joanne Burman of BP archive (1950-70) University of Warwick, Marieke Smulders of Gerard Klijins (1970s) collection in Katholiek Documentatie Centrum, Radboud Universiteit Netherlands, Ronald Codrai archive (1948-55) and Justin Codrai of Abu Dhabi National Archive, and Arabian Gulf Digital Archives. We owe a huge debt of gratitude to the young Emiratis with whom we came into contact while teaching, as well as Emirtati neighbors who generously shared insights into their daily lives.

\section{Authors' contributions}

The author read and approved the final manuscript.

\section{Äuthors' information}

Mamun Rashid teaches Building Construction in Architectural Engineering Department at the University of Sharjah. Educated in Architecture at the Bangladesh University of Engineering and Technology (BUET), Mamun completed his PhD from the University of New South Wales, Australia (recipient of New South Global Scholarship). He is deeply passionate about construction innovations. His research interests also include liveability, sustainable design, building technology, urban housing and urban form. Mamun is also a licensed architect in Bangladesh. He has published in the Journal of Urban Design, Urban Regeneration and Renewal, Architectural Theory Review, Journal of Architecture, Journal of Cultural Geography and Frontiers of Architectural Research Journal. Dilshad Ara taught Architectural History and Design at the Department of Architectural Engineering in the United Arab Emirates University (UAEU) till 2016. She was educated in Architecture at the Bangladesh University of Engineering and Technology (BUET) and at the University of Melbourne (PhD). Dilshad also taught at UNSW (University of New South Wales) Sydney, Australia and at the University of Asia Pacific. Her book chapter on 'Culture of Space' in Timo Myllyntaus's, Thinking through the Environment, appeared in 2011. Her more recent papers on vernacular architecture are published in the Urban Regeneration and Renewal, Architectural Theory Review, Journal of Architecture, Journal of Cultural Geography and Frontiers of Architectural Research Journal. Dilshad has practiced widely as an architect. Her field of interest includes: vernacular dwellings, technology and culture, history and housing, methods in architectural documentation.

Salem Buhashima Abdalla currently teaches at the Department of Architectural Engineering, University of Sharjah. Salem does research in building technology, CAAD and building information modelling. His current interest includes research on developing methods of digital technology in early design phase.

\section{Funding}

Not applicable.

\section{Declarations}

Ethics approval and consent to participate

No human, animal or plants data are included.

Consent for publication

Not applicable.

\section{Competing interests}

No competing interests.

\section{Author details}

${ }^{1}$ Department of Architectural Engineering, University of Sharjah, P.O.Box: 27272, Sharjah, United Arab Emirates. ${ }^{2}$ 48-O Indira Road, Dhaka 1215, Bangladesh.

Received: 1 Auqust 2021 Accepted: 14 December 2021

Published online: 03 February 2022 


\section{References}

Abed I, Hellyer P (2001) United Arab emirates: a new perspective. Trident Press, London

ADHA (2018) Spaces upto 8 bedrooms: Bayti Designs. Abu Dhabi Housing Authority. https://www.adha.gov.ae/baytiweb/index.html. Retrieved 19 June 2019

AFP (2014) Preserving tribal customs that define being an Emirati. Khaleej Times. https://www.khaleejtimes.com/nation/general/preserving-tribalcustoms-that-define-being-an-emirati. Retrieved 10 Feb 2020

Ahmad A (2016). Housing authority issues new designs for Emirati homes. The National https://www.thenationalnews.com/uae/housing-authorityissues-new-designs-for-emirati-homes-1.202177. Retrieved 2 May 2019

Al Otaiba H (2017) This country is dedicated to gender equality. Opinion. https://www.thenational.ae/opinion/this-country-is-dedicated-to-gender-equality-1.80939. Retrieved Oct 162017

Alawadi K, Benkraouda O (2018) What happened to Abu Dhabi's urbanism? The question of regional integration. J Urban Des 23(3):367-394. https:// doi.org/10.1080/13574809.2017.1361786

Al-Fahim M (1998) From rags to riches: a story of Abu Dhabi. I. B. Tauris, London

Al-Mansoori MAJ (1997) Government low-cost housing provision in the United Arab Emirates: the example of the Federal Government low-cost housing programme. PhD Newcastle University Doctoral Thesis, Newcastle University, Newcastle

Al-Nakib F (2020) Kuwait transformed: a history of oil and urban life. Stanford University Press, Palo Alto

Al-Zubaidi MSS (2007) The sustainability potential of traditional architecture in the Arab world-with reference to domestic buildings in the UAE. PhD Doctoral thesis, University of Huddersfield, Huddersfield

Amaireh AA (2011) The Bedouin Tent in comparison with UAE housing provision. Open House Int 36(4):82

Bianca S (2000) Urban form in the Arab world: past and present. Thames \& Hudson, London; New York

Boussaa D (2006) A future to the past: the case of Fareej Al-Bastakia in Dubai, UAE. Proc Semin Arabian Studies 36:125-138

Boussaa D (2018) Urban regeneration and the search for identity in historic cities 48. Sustainability 10(48):16

Chiu RLH (2004) Socio-cultural sustainability of housing: a conceptual exploration. Hous Theory Soc 21(2):65-76. https://doi.org/10.1080/1403609041 0014999

Cole DP (2003) Where have the Bedouin gone? Anthropol Q 76:235-267

Coles A, Jackson P (2007) Windtower. Stacey International, London

Curtis WJ (1996) Modern architecture since 1900, vol 2. Phaidon, London

Damlūji SS (2006) The Architecture of the United Arab Emirates. Garnet Publishing Ltd, Reading

Dempsey MC (2014). Castles in the Sand: a city planner in Abu Dhabi. McFarland \& Co, Jefferson, NC

Dickson HRP (1949) The Arab of the Desert: a glimpse into badawin life in Kuwait and Sau'di Arabia. George Allen \& Unwin, London

Duncan O, Tomic S (2016) Abu Dhabi, UAE Architecture and Globalisation in the Persian Gulf Region. Routledge, New York, pp 129-154

Elsheshtawy Y (2011) Informal encounters: mapping Abu Dhabi's Urban public spaces. Built Environ 37(1):92-113

Moshashai D (2018) National Visions as Instruments of Soft-power in the Gulf Region: the Case of the UAE and Its"Vision 2021". Johns Hopkins University SAIS Europe

Fathy $\mathrm{H}$ (1972) The Arab house in the urban setting: past, present and future. Longman, London

Frampton K, Futagawa Y (1983). Modern architecture: ADA Edita

Fraser M, Golzari N (2016) Architecture and globalisation in the Persian Gulf Region. Routledge, New York

Fuccaro N (2014) Rethinking the History of Port Cities in the Gulf. In: Potter LG (ed), The Persian Gulf in modern times. Palgrave Macmillan, New York

Greenhalgh P (1990) Modernism in design. Reaktion books, London

Hashim ARB (2019) Planning Abu Dhabi: an urban history. Routledge, New York

Hawker R (2008) Traditional architecture of the Arabian Gulf: building on desert tides. WIT Press, Southampton

Hawker R (2015) Traditional architecture in the UAE. Digital Heritage in the UAE. https://rhawker.me/traditional-architecture-in-the-uae/. Retrieved 16 Oct 2016
Heard-Bey F (1997) The tribal society of the UAE and its traditional economy In: Maksoud C, Ghareeb E, Al-Abed I (eds) Perspectives on the United Arab Emirates. Trident Press, London, pp 254-272

Heard-Bey F (1982) From Trucial States to United Arab Emirates. A Society in Transition

Hill J (1998) Occupying architecture : between the architect and the user. Routledge, London, New York

Hill J (2003) Actions of architecture : architects and creative users. Routledge, London, New York

Katodrytis G, Mitchell K (2015) UAE and the Gulf: architecture and urbanism now. Wiley, West Sussex

Kay S, Zandi D (1991) Architectural heritage of the Gulf. Motivate Publishing, Dubai

Kent S (1993) Activity areas and architecture: an interdisciplinary view of the relationship between use of space and domestic built environments In: Kent S (ed) Domestic architecture and the use of space: an interdisciplinary cross-cultural study. Cambridge University Press, Cambridge, p. 1-8

Khan MA (1995) Sustainable development: the key concepts, issues and implications. Keynote paper given at the international sustainable development research conference, 27-29 March 1995, Manchester, UK. Sustain Dev 3(2):63-69

Kiet A (2011) Arab culture and urban form. Focus 8(1):10

King AD (2003) Buildings and society: essays on the social development of the built environment. Routledge, New York

Kumar NPK (2016) A new discourse on everyday spaces in the UAE. Culture \& Arts. http://gulfnews.com/culture/arts/a-new-discourse-on-every day-spaces-in-the-uae-1.1861648. Retrieved 15 Sept 2016

Kyriazis A, Almehairi A, Seri I (2017) The morphology of Abu Dhabi's superblocks: a modernist vision. Athens J Architect 3(4):373-394. https://doi. org/10.30958/aja.3-4-3

Lancaster W, Lancaster F (2011) Honour is in contentment: life before oil in Ras Al-Khaimah (UAE) and some neighbouring regions, vol 25. Walter de Gruyter GmbH \& Co, Berlin

Lawrence RJ (1987) Housing, dwellings and homes: design theory, research and practice. Wiley

Leech N (2016). A nation at home: how Emiratis made sha'bi housing their own. The National. http://www.thenational.ae/arts-life/the-review/ 20160526/a-nation-at-home-how-emiratis-made-shabi-housing-theirown. Retrieved 16 Oct 2017

MEI (2008) Viewpoints special edition: architecture and urbanism in the middle east. Middle East Institute (MEI), Washington

Melhuish C, Campkin B, Ross R (eds) (2014) Heritage and renewal in Doha. Urban Pamphleteer, vol 4. UCL Urban Laboratory, London

Othman Z, Aird R, Buys L (2015) Privacy, modesty, hospitality, and the design of Muslim homes: a literature review. Front Architect Res $4(1): 12-23$

Pallathucheril V (2015) New hearts for two gulf cities. Archit Des 85(1):92-99. https://doi.org/10.1002/ad.1858

Potter LG (2017) Society in the Persian Gulf: Before and After Oil Center for International and Regional Studies_CIRS Occasional Papers, vol 18. Georgetown University Qatar, Qatar, pp. 1-45

Potts DT (2012) In the land of the Emirates: the archaeology and history of UAE. Trident Press, Abu Dhabi

Ragette F (2003) Traditional domestic architecture of the Arab region. Edition Axel Menges, Sharjah

Rapoport A (1977) Human aspects of urban form, vol 3. Pergamon Oxford, Oxford

Rapoport A, El Sayegh S (2005) Culture, architecture, and design. Locke science publishing Company, Chicago

Reisz T (2013) Plans the earth swallows: an interview with Abdulrahman Makhlouf. Portal 9|Stories and Critical Writing about the City, Spring. 2013(2)

Remali AM, Salama AM, Wiedmann F, Ibrahim HG (2016) A chronological exploration of the evolution of housing typologies in Gulf cities. City Territ Archit 3(1):14

Rosen SA, Saidel BA (2010) The camel and the tent: an exploration of technological change among early pastoralists. J Near Eastern Studies 69(1):63-77. https://doi.org/10.1086/654940 
Sadik MT, Snavely WP (1972) Bahrain, Qatar, and the United Arab Emirates: colonial past, present problems, and future prospects. Lexington Books, Lexington, Mass.

Saidel BA (2009) Coffee, gender, and tobacco: observations on the history of the Bedouin Tent. Anthropos (H. 1) 104:179-186

Salem F (2009) Majlis is a key feature of civilisation in UAE. UAE Culture. http:// gulfnews.com/news/uae/culture/majlis-is-a-key-feature-of-civilisation-inuae-1.69497. Retrieved 16 Oct 2016

Sobh R, Belk R (2011) Domains of privacy and hospitality in Arab Gulf homes. J Islamic Marketing 2(2):125-137

Sobh R, Belk RW, Wilson JA (2013) Islamic Arab hospitality and multiculturalism. Mark Theory 13(4):443-463

Thaman KH (2002) Shifting sights: the cultural challenge of sustainability. High Educ Pol 15(2):133-142

Thesiger W (1950) Desert borderlands of Oman. Geogr J 116(4/6):137-168

Till J (2009) Architecture depends. MIT Press, Cambridge, Mass.

Trench R (ed) (1996) Gazetteer of Arabian tribes. Farnham Common: Archive Editions

Turner JFC (1976) Housing by people: towards autonomy in building environments. Marion Boyars, London

Turner JF, Fichter R (eds) (1972) Freedom to build: dweller control of the housing process. Macmillan, New York

UAE Government (2018) Gender equality. UN's 2030 Agenda. https://gover nment.ae/en/about-the-uae/leaving-no-one-behind/5genderequality. Retrieved 16 Oct 2018

UPC (2010) Pearl Villa Rating System: Design \& Construction, Version 1.0, April 2010. https://pages.dmt.gov.ae/-/media/E004806DE83B4633A9A2B9ACF D1EA1E7.ashx. Retrieved 16 Oct 2016

UPC (2011) Abu Dhabi Public Realm Design Manual. In: A. D. U. P. Council (ed) Abu Dhabi 2030 Urban Structure Framework Plan. Abu Dhabi Urban Planning Council, Abu Dhabi

Urban F (2013) Tower and slab: histories of global mass housing. Routledge, New York

WAM. (2015). UPC to launch its new vision for future at Cityscape 2015. http:// www.wam.ae/en/news/emirates/1395281523069.html. Retrieved 17 Dec 2016

Wimsatt A (2010) The houses that John built. The National. http://www.thena tional.ae/arts-culture/the-houses-that-john-built\#full. Retrieved 16 Oct 2016

Winter T (2016) Urban sustainability in the Arabian Gulf: air conditioning and its alternatives. Urban Studies 53(15):3264-3278

\section{Publisher's Note}

Springer Nature remains neutral with regard to jurisdictional claims in pub-

lished maps and institutional affiliations.

\section{Submit your manuscript to a SpringerOpen ${ }^{\circ}$ journal and benefit from:}

- Convenient online submission

- Rigorous peer review

- Open access: articles freely available online

- High visibility within the field

- Retaining the copyright to your article

Submit your next manuscript at $\gg$ springeropen.com 